\title{
Rheological behavior of Brazilian Cherry (Eugenia uniflora L.) pulp at pasteurization temperatures
}

\author{
Comportamento reológico da polpa de pitanga (Eugenia uniflora L.) em temperaturas de pasteurização
}

Alessandra Santos LOPES $^{1 \star}$, Rafaella de Andrade MATTIETTO², Hilary Castle de MENEZES 3 , Luiza Helena Meller da SILVA ${ }^{1}$, Rosinelson da Silva PENA ${ }^{1}$

\begin{abstract}
The rheological behavior of Brazilian Cherry (Eugenia uniflora L.) pulp in the range of temperatures used for pasteurization $\left(83\right.$ to $\left.97^{\circ} \mathrm{C}\right)$ was studied. The results indicated that Brazilian Cherry pulp presented pseudoplastic behavior, and the Herschel-Bulkley model was considered more adequate to represent the rheological behavior of this pulp in the range of temperatures studied. The fluid behavior index ( $\mathrm{n}$ ) varied in the range from 0.448 to 0.627 . The effect of temperature on the apparent viscosity was described by an equation analogous to Arrhenius equation, and a decrease in apparent viscosity with an increase in temperature was observed.

Keywords: Brazilian cherry; fruit pulp; rheology; activation energy.
\end{abstract}

\section{Resumo}

Neste trabalho, foi estudado o comportamento reológico da polpa de pitanga na faixa de temperatura de pasteurização de 83 a $97{ }^{\circ} \mathrm{C}$. Os resultados indicaram que a polpa apresentou comportamento pseudoplástico e o modelo de Herschel-Bulkley foi considerado o mais adequado para representar o comportamento reológico do produto nas temperaturas estudadas. Os índices de comportamento de fluido (n) variaram na faixa de 0,448 a 0,627. O efeito da temperatura sobre a viscosidade aparente pôde ser descrito pela equação análoga à de Arrenhius, observando-se a diminuição da viscosidade aparente da polpa de pitanga com o aumento da temperatura.

Palavras-chave: pitanga; polpa de fruta; reologia; energia de ativação.

\section{Introduction}

Brazilian Cherry is indigenous to Brazil extending over a wide area, from the North to the South. It is found growing in the wild along the banks of streams and in the edge the forests, but it is also commonly grown in many parts of Brazil, mainly in the Southeast region. Outside Brazil, Brazilian Cherry is also grown in several countries such as United States (Florida, Hawaii, and California), India, Ceylon, China, Algeria, France, and Cuba (CONSOLINI; SARUBBIO, 2002; MIELKE; SCHAFFER, 2010).

Fruit pulp can be used as raw material in the food industry to obtain various products, such as nectars, jams, ice-creams etc., products that can also be sold directly to consumers. Knowledge of the rheological properties of this fruit pulp is fundamental to evaluate its quality and also for its use in engineering to calculate flow rate, in the selection of pumps, and determination of pressure loss in pipes, etc. (RAO; STEFFE, 1992; SARAVACOS; MAROULIS, 2001; SATO; CUNHA, 2009).

Fruit pulps are generally characterized as non-Newtonian fluids as a result of complex interactions amongst their components. These kinds of fluid are generally described by empirical rheological models that represent the most convenient rheogram fit. The most widely used models are the Power Law (RAO; STEFFE, 1992; HOLDSWORTH, 1993; PELEGRINE; SILVA; GASPARETTO, 2002; HAMINIUK et al., 2006) and the Herschel-Bulkley (RAO; STEFFE, 1992; HOLDSWORTH, 1993; PELEGRINE; SILVA; GASPARETTO, 2002; DUTTA et al., 2006).

The rheological properties of a number of fruit purees, such as peach puree (GUERRERO; ALZAMORA, 1997), mango puree (GUERRERO; ALZAMORA, 1997; PELEGRINE; SILVA; GASPARETTO, 2002; DAK; VERMA; JAAFFREY, 2007), and tropical fruit puree (guava, pineapple and papaya) (PELEGRINE; SILVA; GASPARETTO, 2002; AHMED; RAMASWAMY, 2004; SÁNCHEZ et al., 2009) and cashew juice (MOREIRA et al., 2005) have been determined, and the Power Law model was used to describe the flow behavior. Until now, however, there have been no reports on the rheological behavior of Brazilian Cherry.

The rheological behavior of fruit juices and pulps is associated to the levels of soluble solids in suspension and as a function of the form, size and concentrations of the suspended

${ }^{1}$ Instituto de Tecnologia, Faculdade de Engenharia de Alimentos, Universidade Federal do Pará - UFPA, Belém, PA, Brasil, e-mail: aslopes@ufpa.br

${ }^{2}$ Empresa Brasileira de Pesquisa Agropecuária - EMBRAPA Amazônia Oriental, CEP 66095-100, Belém, PA, Brasil

3 Universidade Estadual de Campinas - UNICAMP, CEP 13083-862, Campinas, SP, Brasil

${ }^{*}$ Corresponding author 
particles and the structure of the system. The literature on the rheology of fruit derivatives has established that temperature, soluble solids concentration, pectin content, and insoluble solids content are the main factors responsible for the rheological behavior (RAO; STEFFE, 1992; JUSZCZAK; FORTUNA, 2004; HAMINIUK et al., 2006).

Different temperatures are applied in the various steps of fruit juice and pulp processing, for example during pasteurization and cooling. Thus, the rheological behavior of these fluids should be studied in the various temperature ranges used in industrial processes (MARCOTTE; HOSHAHILI; RAMASWAMY, 2001; SARAVACOS; MAROULIS, 2001).

At rest, fruit pulps, which are dispersions of molecules or asymmetric particles, show a disordered state, but when subjected to shear stress, their molecules or particles tend to orient themselves toward the applied force. The greater the force applied, the greater the ordination and hence the lower the apparent viscosity. The pseudoplastic fluids are also known as shear-thinning fluids, since their apparent viscosity decreases as the shear rate is increased (RAO; STEFFE, 1992; RAO, 1999; KROKIDA; MAROULIS; SARAVACOS, 2001; SATO; CUNHA, 2009).

There are two rheological models that generally describe the rheological behavior of fruit juice and pulps: the Ostwaldde-Waele model (or Power Law) (Equation 1) and the HerschelBulkley model (or Generalized Power Law) (Equation 2); their difference is the inclusion of the yield stress $\left(\sigma_{\mathrm{o}}\right)$ in Equation 2 (RAO; STEFFE, 1992; HOLDSWORTH, 1993; AHMED; RAMASWAMY, 2004).

$$
\sigma=k \dot{\gamma}^{n}
$$

$$
\sigma=\sigma_{o}+k \dot{\gamma}^{n}
$$

where: $\dot{\gamma}=$ shear rate $\left(\mathrm{s}^{-1}\right), \sigma=$ shear stress $(\mathrm{Pa}), \sigma_{\mathrm{o}}=$ yield stress $(\mathrm{Pa}), \mathrm{k}=$ consistency index $\left(\mathrm{Pa} . \mathrm{s}^{\mathrm{n}}\right)$, and $\mathrm{n}=$ flow behavior index (non-dimensional)

In the Brazilian food industry, Brazilian Cherry fruit has mainly been used to produce pulp and juice, which shows good economic potential due to the consumer appeal arising from its high concentration of antioxidant compounds (EINBOND et al., 2004; SPADA et al., 2008; CELLI; PEREIRANETTO; BETA, 2011).

The objective of the present study was to evaluate the rheological behaviour of Brazilian Cherry pulp in the range of pasteurization temperatures from 83 to $97^{\circ} \mathrm{C}$.

\section{Materials and methods}

\subsection{Raw material}

Brazilian Cherry fruits $(9 \mathrm{~kg})$ were obtained from a farm in Valinhos, São Paulo, Brazil. Immediately after harvest, the fruits were transported to the Pilot Plant of Food Technology Department at UNICAMP, where they were selected, washed, and sanitized with chlorine solution $\left(60 \mathrm{mg} \cdot \mathrm{L}^{-1}\right)$ for 30 minutes.
The fruits that presented visual defects, mechanical damage, and attack by fungi and wood pests were discarded. The extraction process was carried out in duplicate using a BERTUZZI brush pulper. The samples were packed in plastic bags $(500 \mathrm{~mL})$ and stored under freezing temperature $\left(-20^{\circ} \mathrm{C}\right)$ until analyses.

\subsection{Physical and physicochemical analyses}

The analyses were carried out according to AOAC methods (ASSOCIATION... 1997): $\mathrm{pH}$ (method ${ }^{\circ}$ 981.12); total titratable acidity (method $\mathrm{n}^{\circ} 942.15$ ); reducing and total sugars (methods $n^{\circ} 925.35$ and 925.36); proteins (method $n^{\circ} 920.152$ ); lipids (method $\mathrm{n}^{\circ} 968.20$ ), and ashes (method $\mathrm{n}^{\circ} 940.26$ ). Soluble solids ( ${ }^{\circ} \mathrm{Brix}$ ) were evaluated based on the direct reading of degrees Brix of the sample at $20^{\circ} \mathrm{C}$ using a LEICA AR200 digital refractometer, and the total solids were determined using a GEHAKA IV 2002 infrared moisture analyser.

\subsection{Rheological characterization}

The rheological analyses of the Brazilian Cherry pulp were carried out using a BROOKFIELD RV-DV III digital rheometer with a coaxial cylinder geometry (Ultra Low Viscosity Adapter - ULA) and a BROOKFIELD TC500 thermostatically controlled water bath. The analyses were carried out in triplicate varying the velocity in both the increasing (10 to $250 \mathrm{rpm}$ ) and decreasing (250 to $10 \mathrm{rpm}$ ) modes with increments of $10 \mathrm{rpm}$ every 15 seconds. The total run time was 6.30 minutes, within which 50 measurements of apparent viscosity (mPa.s), shear stress $(\mathrm{Pa})$, and shear rate $\left(\mathrm{s}^{-1}\right)$ were obtained. The temperatures evaluated were $83,85,90,95$, and $97^{\circ} \mathrm{C}$ in addition to $20^{\circ} \mathrm{C}$, which was used as the reference temperature. Samples of $16.0 \mathrm{~mL}$ of Brazilian cherry pulp were used for each experiment, and sample reuse was avoided due to the possible changes in rheological properties after heating.

The effect of temperature on the apparent viscosity $\left(\eta_{\mathrm{a}}\right)$ at a specific shear rate was evaluated by the equations analogous to Arrhenius equation (Equation 3) (RAO; STEFFE, 1992; MARCOTTE, HOSHAHILI; RAMASWAMY, 2001; JUSZCZAK; FORTUNA, 2004). The Herschel-Bulkley model was used to obtain the apparent viscosity values at different shear rates.

$\eta_{\mathrm{a}}=\eta_{\mathrm{o}} \cdot \exp ^{\left(\frac{\mathrm{E}_{\mathrm{a}, t, \eta}}{\mathrm{R} \cdot \mathrm{T}}\right)}$

where: $\eta_{\mathrm{a}}=$ apparent viscosity (Pa.s); $\eta_{\mathrm{o}}=$ constant (Pa.s); $\mathrm{E}_{\mathrm{at},} \eta=$ activation energy $\left(\mathrm{J} \cdot \mathrm{mol}^{-1}\right) ; \mathrm{R}=$ gas constant $\left(8.3144 \mathrm{~J} \cdot \mathrm{mol}^{-1} \cdot \mathrm{K}^{-1}\right)$; and $\mathrm{T}=$ temperature $(\mathrm{K})$.

\subsection{Statistical analysis}

A non-linear fit (Quasi-Newton) was made for the Power Law (Ostwald-de-Waele) and Generalized Power Law (Herschel-Bulkley) models using the STATISTICA ${ }^{\star}$ version 5.0 software (STATSOFT..., 1995). Ascending and descending curves were used to obtain the fits for the models, the mean value of shear stress was calculated for each shear rate at the different temperatures evaluated. The average values of ascending and descending curves were used because the fluid did not present 
thixotropy, as described by Gasparetto and Guimarães (2000). The following statistical parameters were evaluated to determine the adequacy of the models: coefficient of determination $\left(\mathrm{R}^{2}\right)$, chi-square $\left(\chi^{2}\right)$, and the sum of squared residues (SSR). The higher the value of $\chi^{2}$, the greater the difference between the frequencies observed and those predicted by the model. Thus, the model that best fitted the data was that with the highest $\mathrm{R}^{2}$ values and the lowest for $\chi^{2}$ and SSR values. The Arrhenius Equation was fitted using non-linear regression using the same software.

\section{Results and discussion}

\subsection{Physical and physicochemical characterization of Brazilian Cherry pulp}

Table 1 shows the results of composition obtained for the Brazilian Cherry pulp used in this study. The major constituent of pulp Brazilian Cherry are total sugars (7.97\%), especially reducing sugars $(7.80 \%)$, which accounted for $89.7 \%$ and $87.8 \%$ of the total solids of the pulp, respectively. Similar composition for this fruit was observed by Lederman, Bezerra and Calado (1992) and Santos, Silva and Alves (2006).

As observed for other fruits, the values of proteins $(0.68 \%)$ and lipids $(0.49 \%)$ are below $2 \%$. Bagetti et al. (2011) reported values of $1.4 \%$ and $0.4 \%$ for proteins and lipids in Brazilian cherry fruit, respectively.

\subsection{Rheological behavior of Brazilian Cherry pulp}

Figure 1 shows the flow curves for Brazilian Cherry pulp at the different temperatures studied. The graph represents the mean experimental points and their respective curves adjusted to the Herschel-Bulkley model. Non-Newtonian behavior was observed, as shown by the non-linearity between the shear stress and shear rate applied. In addition, the slopes of the flow curves decreased with an increase in shear rate, evidence of the decrease in apparent viscosity with increase in shear rate, confirming the pseudoplastic behavior of the Brazilian Cherry pulp.

The majority of food fluids presents pseudoplastic behavior the apparent viscosity decreases with an increase in shear rate (RAO; STEFFE, 1992; SARAVACOS; MAROULIS, 2001), as can be seen in Figure 2. Rao and Steffe (1992) and Saravacos and Maroulis (2001) reported the pseudoplastic behavior of fruit

Table 1. Physico-chemical characterization of Brazilian Cherry pulp.

\begin{tabular}{lc}
\hline \multicolumn{1}{c}{ Parameter } & Value $^{*}$ \\
\hline $\mathrm{pH}$ & $3.34 \pm 0.01$ \\
Total titratable acidity (g citric acid. $100 \mathrm{~g}^{-1}$ ) & $1.23 \pm 0.02$ \\
Soluble solids (as ${ }^{\circ}$ Brix) & $7.97 \pm 0.06$ \\
Total solids (\%) & $8.88 \pm 0.02$ \\
Reducing sugars (g glucose. $100 \mathrm{~g}^{-1}$ ) & $7.80 \pm 0.03$ \\
Total sugars (g glucose.100g ${ }^{-1}$ ) & $7.97 \pm 0.13$ \\
Proteins (\%) & $0.68 \pm 0.01$ \\
Lipids (\%) & $0.49 \pm 0.03$ \\
Ashes (\%) & $0.37 \pm 0.00$ \\
\hline
\end{tabular}

${ }^{*}$ Mean of triplicate \pm standard deviation (wet weight basis). juices and pulps and verified that this deviation from Newtonian behavior was determined by the pulp content. Rao (1999) and Sato and Cunha (2009) showed that the rheological behavior of fruit juices and pulps was related to the levels of suspended soluble solids as a function of the form, size, and concentration of the suspended particles and the structure of the system. The presence of pectic substances and/or dispersed solid particles is responsible for the non-Newtonian behavior which can be described by the Power Law, Herschel-Bulkley, and Bingham models (SARAVACOS; MAROULIS, 2001; DAK; VERMA; JAAFFREY, 2007).

The influence of temperature on the behavior of the curves in Figures 1 and 2 is quite pronounced; it can be seen that the curve prepared at a temperature of $20^{\circ} \mathrm{C}$ (reference temperature) is in a distinct range of values for shear stress and viscosity when compared to those prepared at pasteurization temperatures $\left(83,85,90,95\right.$, and $\left.97^{\circ} \mathrm{C}\right)$. According to Rao and Steffe (1992), Marcotte, Hoshahili and Ramaswamy (2001) and Juszczak and Fortuna (2004), and many other authors, temperature is one of the major factors that affect the viscosity of fruit pulps.

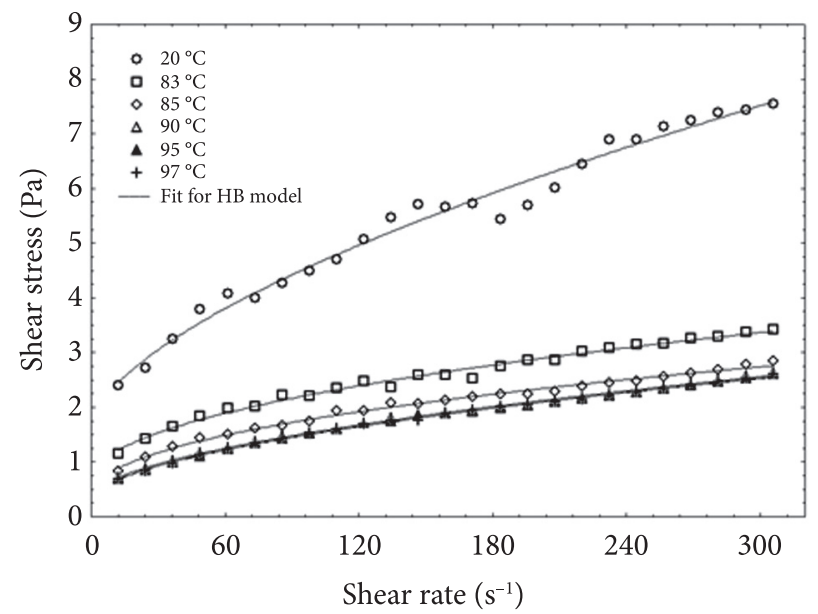

Figure 1. Relationship between shear stress and shear rate for Brazilian cherry pulp at different temperatures.

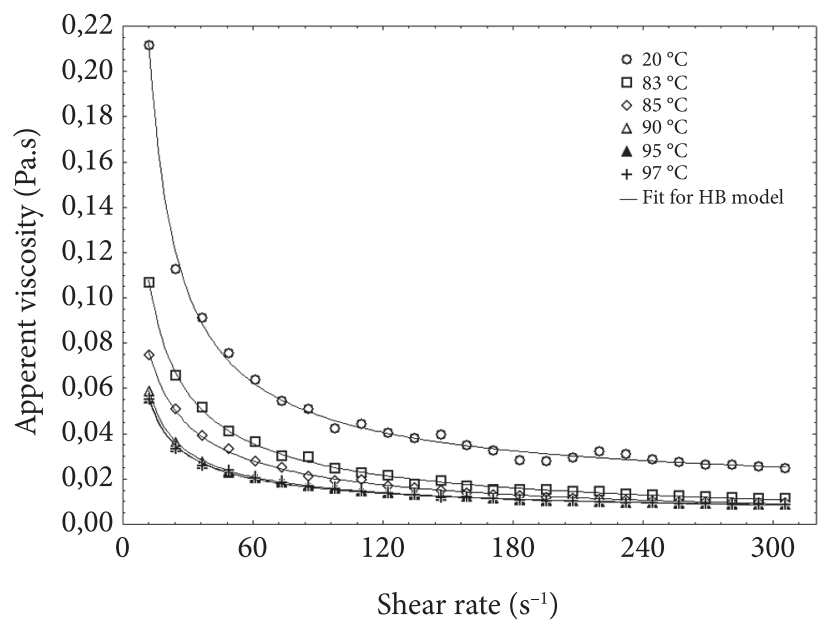

Figure 2. Relationship between apparent viscosity and shear rate for Brazilian cherry pulp at different temperatures. 
The values for apparent viscosity of the Brazilian Cherry pulp varied from 0.008 to 0.212 Pa.s (Figure 2) for the temperature/shear rate binomials of $97{ }^{\circ} \mathrm{C} / 306 \mathrm{~s}^{-1}$ and $20{ }^{\circ} \mathrm{C} / 12 \mathrm{~s}^{-1}$, respectively.

Table 2 shows the values obtained for the apparent viscosity of Brazilian Cherry pulp at shear rates of 100,200, and $300 \mathrm{~s}^{-1}$. As can be seen in Figure 2, a decrease in apparent viscosity is verified when the increases in temperature and shear rate are considered separately.

These values are relevant in industrial processing operations when the shear rate is greater than $100 \mathrm{~s}^{-1}$ (VIDAL, 2006).

\subsection{Determination of the rheological parameters of Brazilian Cherry pulp}

Table 3 presents the values for the rheological parameters and the statistical results obtained for Brazilian Cherry pulp at temperatures of $20,83,85,90,95$ and $97^{\circ} \mathrm{C}$, from the fit for the Power Law and Herschel-Bulkley models using the average value of the ascending and descending curves in triplicate. It shows that the values for the behavior index $(\mathrm{n})$ are always less than unity indicating a pseudoplastic character of the Brazilian Cherry pulp. This rheological parameter varied from 0.346 to 0.446 for the Power Law model and from 0.448 to 0.627 for the Herschel-Bulkley model.

Table 2. Apparent viscosity of Brazilian Cherry pulp.

\begin{tabular}{cccc}
\hline \multirow{2}{*}{$\begin{array}{c}\text { Temperature } \\
\left({ }^{\circ} \mathrm{C}\right)\end{array}$} & \multicolumn{3}{c}{ Apparent viscosity (mPa.s) } \\
\cline { 2 - 4 } & $100 \mathrm{~s}^{-1}$ & $200 \mathrm{~s}^{-1}$ & $300 \mathrm{~s}^{-1}$ \\
\hline $20^{* *}$ & $45.98 \pm 2.68^{\mathrm{a}}$ & $29.10 \pm 1.59^{\mathrm{a}}$ & $24.67 \pm 1.07^{\mathrm{a}}$ \\
83 & $22.53 \pm 1.71^{\mathrm{b}}$ & $14.96 \pm 2.91^{\mathrm{b}}$ & $11.21 \pm 1.63^{\mathrm{b}}$ \\
85 & $17.75 \pm 1.52^{\mathrm{bc}}$ & $11.45 \pm 1.04^{\mathrm{bc}}$ & $9.31 \pm 0.71^{\mathrm{bc}}$ \\
90 & $15.76 \pm 1.49^{\mathrm{c}}$ & $10.50 \pm 1.05^{\mathrm{c}}$ & $8.62 \pm 0.66^{\mathrm{bc}}$ \\
95 & $15.57 \pm 1.61^{\mathrm{c}}$ & $10.39 \pm 1.00^{\mathrm{c}}$ & $8.52 \pm 0.70^{\mathrm{c}}$ \\
97 & $15.61 \pm 1.52^{\mathrm{c}}$ & $10.43 \pm 1.20^{\mathrm{c}}$ & $8.53 \pm 0.70^{\mathrm{c}}$
\end{tabular}

${ }^{*}$ Mean of triplicate \pm standard deviation (wet weight basis). ${ }^{*}$ Reference temperature. Mean values in the same column followed by different subscript letters are significantly different $(\mathrm{p}<0.05)$

Table 3. Rheological and statistical parameters for Brazilian Cherry pulp.

\begin{tabular}{|c|c|c|c|c|c|c|}
\hline \multicolumn{7}{|c|}{ Power Law } \\
\hline & $20^{\circ} \mathrm{C}$ & $83^{\circ} \mathrm{C}$ & $85^{\circ} \mathrm{C}$ & $90^{\circ} \mathrm{C}$ & $95^{\circ} \mathrm{C}$ & $97^{\circ} \mathrm{C}$ \\
\hline $\mathrm{K}\left(\mathrm{Pa} \cdot \mathrm{s}^{\mathrm{n}}\right)$ & 0.738 & 0.463 & 0.325 & 0.213 & 0.201 & 0.197 \\
\hline $\mathrm{n}$ & 0.403 & 0.346 & 0.372 & 0.434 & 0.442 & 0.446 \\
\hline $\mathrm{R}^{2}$ & 0.974 & 0.986 & 0.992 & 0.995 & 0.996 & 0.996 \\
\hline$\chi^{2}$ & 0.299 & 0.052 & 0.025 & 0.023 & 0.019 & 0.020 \\
\hline$S S R$ & 1.443 & 0.132 & 0.055 & 0.032 & 0.025 & 0.028 \\
\hline \multicolumn{7}{|c|}{ Herschel-Bulkley } \\
\hline & $20^{\circ} \mathrm{C}$ & $83^{\circ} \mathrm{C}$ & $85^{\circ} \mathrm{C}$ & $90^{\circ} \mathrm{C}$ & $95^{\circ} \mathrm{C}$ & $97^{\circ} \mathrm{C}$ \\
\hline$\tau_{\mathrm{o}}(\mathrm{Pa})$ & 1.674 & 0.621 & 0.301 & 0.351 & 0.291 & 0.299 \\
\hline $\mathrm{K}\left(\mathrm{Pa} . \mathrm{s}^{\mathrm{n}}\right)$ & 0.163 & 0.179 & 0.189 & 0.091 & 0.100 & 0.095 \\
\hline $\mathrm{n}$ & 0.627 & 0.479 & 0.448 & 0.558 & 0.545 & 0.553 \\
\hline $\mathrm{R}^{2}$ & 0.981 & 0.989 & 0.993 & 0.998 & 0.998 & 0.998 \\
\hline$\chi^{2}$ & 0.193 & 0.045 & 0.024 & 0.007 & 0.007 & 0.008 \\
\hline$S S R$ & 1.037 & 0.105 & 0.048 & 0.015 & 0.014 & 0.015 \\
\hline
\end{tabular}

Pelegrine, Silva and Gasparetto (2002), Ahmed and Ramaswamy (2004), Dutta et al. (2006), Dak, Verma and Jaaffrey (2007) showed pseudoplastic behavior for papaya, mango, and pineapple pulps. This effect is clearly more pronounced for whole pulps than for those clarified by centrifugation.

According to Chin et al. (2009) and Sánchez et al. (2009), pummelo juice concentrate and white guava puree showed behavior index $(\mathrm{n})$ values below unity at temperatures from 6 to $75^{\circ} \mathrm{C}$ and 10 to $60^{\circ} \mathrm{C}$, respectively, indicating pseudoplastic behavior.

Saravacos and Maroulis (2001) showed that the values for the behavior index (n) for fruit purees were generally in the range from 0.30 to 0.50 . The variation in this parameter is a function of several variables such as: variety, processing, degree of maturity, and the method for determining rheological parameters.

Guerrero and Alzamora (1997) and Krokida, Maroulis and Saravacos (2001) showed that the consistency index (K) decreased significantly at high temperatures, but the behavior index (n) of fruit purees was not affected.

Comparing the fit for the Power Law and HerschelBulkley models, it can be seen that both models satisfactorily represent the rheological behavior of the Brazilian Cherry pulp. The Herschel-Bulkley model showed higher values for the determination coefficient $\left(\mathrm{R}^{2}\right)$ and lower values in the chi-square test $\left(\chi^{2}\right)$ and also for the sum of squared residues (SSR). Additionally, the Herschel-Bulkley model provides three rheological parameters (yield stress, consistency coefficient, and flow behavior index), when compared with the Power Law model (two parameters), which does not provide the parameter yield stress. According Haminiuk et al. (2006), the yield stress is an important quality control parameter in industrial processes, particularly for comparing the overall characteristics of products manufactured on different production lines.

Since the Herschel-Bulkley model generates more information (yield stress) than the Power Law model, it was chosen to describe the rheological behavior of the Brazilian Cherry pulp.

\subsection{Effect of temperature}

The effect of temperature on the apparent viscosity of Brazilian cherry pulp at a constant shear rate can be described by the Arrhenius equation, in which the apparent viscosity decreases with temperature (Figure 3). The apparent viscosity values generated by Herschel-Bulkley model were used in the construction the Arrhenius model.

The order of magnitude of the activation energy indicates the dependence of the viscosity on the temperature (RAO; STEFFE, 1992; RAO; TATTIYAKUL, 1999; SARAVACOS; MAROULIS, 2001; DAK; VERMA; JAAFFREY, 2007).

According to Table 4, the variation explained around the mean $\left(R^{2}\right)$ showed high values for the shear rates studied. The values for $\mathrm{R}^{2}$ varied from 0.970 to 0.990 , explaining the experimental data using the Arrhenius equation in terms of the 


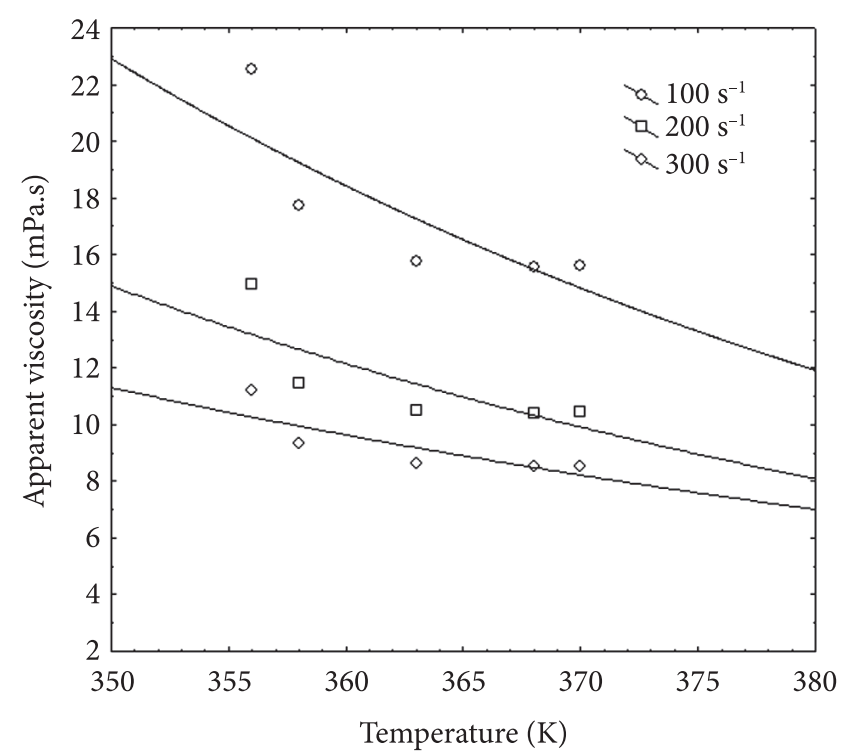

Figure 3. Effect of temperature on the apparent viscosity of Brazilian cherry pulp.

Table 4. Arrhenius parameters and determination coefficients for Brazilian Cherry pulp submitted to shear rates of 100, 200 and $300 \mathrm{~s}^{-1}$.

\begin{tabular}{lrcc}
\hline \multicolumn{1}{c}{ Arrhenius } & \multicolumn{3}{c}{ Shear rate } \\
\cline { 2 - 4 } parameters & $100 \mathrm{~s}^{-1}$ & $200 \mathrm{~s}^{-1}$ & $300 \mathrm{~s}^{-1}$ \\
\hline$\eta_{\mathrm{o}}(\mathrm{mPa} . \mathrm{s})$ & 0.293 & 0.234 & 0.148 \\
$\mathrm{E}_{\mathrm{at}, \eta}\left(\mathrm{kJ} \cdot \mathrm{mol}^{-1}\right)$ & 12.330 & 11.765 & 12.473 \\
$\begin{array}{c}\text { Statistical parameter } \\
\mathrm{R}^{2}\end{array}$ & 0.975 & 0.970 & 0.990 \\
\hline
\end{tabular}

effect of temperature on the apparent viscosity of the Brazilian Cherry pulp.

The value found for the activation energy $\left(\mathrm{E}_{\mathrm{at}} \eta\right)$ for the viscous flow of Brazilian Cherry pulp at $100 \mathrm{~s}^{-1}$ (reference shear rate) was $12.330 \mathrm{~kJ} \cdot \mathrm{mol}^{-1}$ (Table 4), a value close to other values found in the literature for the $\mathrm{E}_{\mathrm{at},} \eta$ of a variety of fruit pulps. Haminiuk et al. (2006) found the value of $11.046 \mathrm{~kJ} \cdot \mathrm{mol}^{-1}$ at a shear rate of $50 \mathrm{~s}^{-1}$ for the $\mathrm{E}_{\mathrm{at},} \eta$ of whole araçá pulp $\left(11.7^{\circ} \mathrm{Brix}\right)$.

\section{Conclusions}

The rheological behavior of Brazilian Cherry pulp in the range of pasteurization temperatures studied can be represented by the Herschel-Bulkley equation. The fluid behavior indexes (n) were below unity characterizing the pseudoplastic behavior of the Brazilian Cherry pulp. The effect of temperature can be evaluated using the Arrhenius-type equation obtaining the activation energy values for the viscous flow of Brazilian Cherry pulp.

\section{Acknowledgements}

The authors are grateful for the financial support provided by $\mathrm{CNPq}$ (The National Council for Scientific and Technological Development).

\section{References}

AHMED, J.; RAMASWAMY, H. S. Response surface methodology in rheological characterization of papaya puree. International Journal of Food Properties, v. 7, n.1, p. 45-58, 2004. http://dx.doi. org/10.1081/JFP-120022495

ASSOCIATION OF OFFICIAL ANALYTICAL CHEMISTS - AOAC. Official methods of analysis. 16th ed. Virginia: AOAC, 1997.

BAGETTI, M. et al. Physicochemical characterization and antioxidant capacity of pitanga fruits (Eugenia uniflora L.). Ciência e Tecnologia de Alimentos, v. 31, n. 1, p. 147-154, 2011. http://dx.doi. org/10.1590/S0101-20612011000100021

CELLI, G. B.; PEREIRA-NETTO, A. B.; BETA, T. Comparative analysis of total phenolic content, antioxidant activity, and flavonoids profile of fruits from two varieties of Brazilian cherry (Eugenia uniflora L.) throughout the fruit developmental stages. Food Research International, v. 44, n. 8, p. 2442-2451, 2011. http://dx.doi. org/10.1016/j.foodres.2010.12.036

CHIN, N. L. et al. Modelling of rheological behaviour of pummelo juice concentrates using master-curve. Journal of Food Engineering, v. 93, n. 2, p. 134-140, 2009. http://dx.doi.org/10.1016/j. jfoodeng.2009.01.005

CONSOLINI, A. E.; SARUBBIO, M. G. Pharmacological effects of Eugenia uniflora (Myrtaceae) aqueous crude extract on rat_s heart. Journal of Ethnopharmacology, v. 81, p. 57-63, 2002. http://dx.doi. org/10.1016/S0378-8741(02)00039-9

DAK, M.; VERMA, R. C.; JAAFFREY, S. N. A. Effect of temperature and concentration on rheological properties of "Kesar" mango juice. Journal of Food Engineering, v. 80, n. 4, p. 1011-1015, 2007. http:// dx.doi.org/10.1016/j.jfoodeng.2006.08.011

DUTTA, D. et al. Rheological characteristics and thermal degradation kinetics of beta-carotene in pumpkin puree. Journal of Food Engineering, v. 76, n. 4, p. 538-546, 2006. http://dx.doi. org/10.1016/j.jfoodeng.2005.05.056

EINBOND, L. S. et al. Anthocyanin antioxidants from edible fruits. Food Chemistry, v. 84, p. 23-28, 2004. http://dx.doi.org/10.1016/ S0308-8146(03)00162-6

GASPARETTO, C. A.; GUIMARÃES, D. H. P. Rheological behavior of pineapple and mango pulps: effect of the measuring systems. Revista de Ciência e Tecnologia, v. 8, n. 16, p. 91-96, 2000.

GUERRERO, S. N.; ALZAMORA, S. M. Effect of $\mathrm{pH}$, temperature and glucose addition on flow behaviour of fruit purees: II. Peach, papaya and mango purees. Journal of Food Engineering, v. 37, n. 1, p. 77-101, 1998. http://dx.doi.org/10.1016/S0260-8774(98)00065-X

HAMINIUK, C. W. I. et al. Influence of temperature on the rheological behavior of whole araça pulp (Psidium cattleianum sabine). LWT - Food Science and Technology, v. 39, n. 4, p. 426-430, 2006.

HOLDSWORTH, S. D. Rheological models used for the prediction of the flow properties of food products: a literature review. Transactions of the Institution of Chemical Engineers, v. 71(C), p. 139-179, 1993.

JUSZCZAK, L.; FORTUNA, T. Effect of temperature and soluble solid content on the viscosity of cherry juice concentrate. International Agrophysics, v. 18, n. 1, p. 17-21, 2004.

KROKIDA, M. K.; MAROULIS, Z. B.; SARAVACOS, G. D. Rheological properties of fluid fruit and vegetable puree products: compilation of literature data. International Journal of Food Properties, v. 4, n. 2, p. 179-200, 2001. http://dx.doi.org/10.1081/JFP-100105186 
LEDERMAN, I. E.; BEZERRA, J. E. F.; CALADO, G. A pitangueira em Pernambuco. Recife: Empresa Pernambucana de Pesquisa Agropecuária - IPA, 1992. 20 p.

MARCOTTE, M.; HOSHAHILI, A. R. T.; RAMASWAMY, H. S. Rheological properties of selected hydrocolloids as a function of concentration and temperature. Food Research International, v. 34, p. 695-703, 2001. http://dx.doi.org/10.1016/S0963-9969(01)00091-6

MIELKE, M. S.; SCHAFFER, B. Photosynthetic and growth responses of Eugenia uniflora L. seedlings to soil flooding and light intensity. Environmental and Experimental Botany, v. 68, p. 113-121, 2010. http://dx.doi.org/10.1016/j.envexpbot.2009.11.007

MOREIRA, P. et al. Effect of concentration on the physical properties of cashew juice. Journal of Food Engineering, v. 66, n. 4, p. 413-417, 2005. http://dx.doi.org/10.1016/j.jfoodeng.2004.04.008

PELEGRINE, D. H.; SILVA, F. C.; GASPARETTO, C. A. Rheological behaviour of pineapple and mango pulps. LWT Food Science and Technology, v. 35, p. 645-648, 2002. http://dx.doi.org/10.1006/ fstl.2002.0920

RAO, M. A. Rheology of fluid and semisolid foods. Gaithersburg: M.D. Aspen Publ., 1999.

RAO, M. A.; STEFFE, J. F. Viscoelastic Properties of Foods. London: Elsevier Applied Science, 1992.

RAO, M. A.; TATTIYAKUL, J. Granule size and rheological behavior of heated tapioca starch dispersions. Carbohydrate Polymers, v. 38, p. 123-132, 1999. http://dx.doi.org/10.1016/S0144-8617(98)00112-X
SÁNCHEZ, C. et al. White guava fruit and purees: textural and rheological properties and effect of the temperature. Journal of Texture Studies, v. 40, n. 3, p. 334-345, 2009. http://dx.doi. org/10.1111/j.1745-4603.2009.00185.x

SANTOS, A. F.; SILVA, S. M.; ALVES, R. E. Armazenamento de pitanga sob atmosfera modificada e refrigeração: I-transformações químicas em pós-colheita. Revista Brasileira de Fruticultura, v. 28 , n. 1 , p. $36-41,2006$. http://dx.doi.org/10.1590/S010029452006000100013

SARAVACOS, G. D.; MAROULIS, Z. B. Transport properties of foods. New York: Marcel Dekker, 2001.

SPADA, P. D. S. et al. Antioxidant, Mutagenic, and Antimutagenic Activity of Frozen Fruits. Journal of Medicinal Food, v. 11, n. 1, p. 144-151, 2008. PMid:18361750. http://dx.doi.org/10.1089/ jmf.2007.598

STATSOFT. Statistica for Windows. Tulsa: StatSoft, Inc., 1995. 2325. [Computer program manual].

SATO, A. C. K.; CUNHA, R. L. Effect of particle size on rheological properties of jaboticaba pulp. Journal of Food Engineering, v. 91, n. 4 , p. 566-570, 2009. http://dx.doi.org/10.1016/j. jfoodeng.2008.10.005

VIDAL, J. R. M. B. et al. Rheological properties of centrifuged mango (Mangifera indica L. cv. Keitt) pulp. Ciência e Agrotecnologia, Lavras, v. 30, n. 5, p. 955-960, 2006. 